\title{
Effects of ozone on the pain and disability in patients with failed back surgery syndrome
}

Danilo Costa Barbosa ${ }^{1,2}$, Jairo Silva dos Ângelos ${ }^{1}$, Gleica Maria Josino de Macena ${ }^{2}$, Francisco Nêuton de Oliveira Magalhães ${ }^{1}$,

\author{
ERICH TALAMONI FonOFF ${ }^{1 *}$
}

${ }^{1}$ Division of Functional Neurosurgery, Department of Neurology, Institute of Psychiatry, Faculdade de Medicina da Universidade de São Paulo (FMUSP), São Paulo, SP, Brazil

${ }^{2}$ Medical School, Universidade Anhembi Morumbi, São Paulo, SP, Brazil

Study conducted under the protocol 0267/09, Capes / Hospital das Clínicas Faculdade de Medicina da Universidade de São Paulo (HC-FMUSP), as open trial, São Paulo, SP, Brazil

Article received: $8 / 1 / 2016$ Accepted for publication: 10/4/2016 *Correspondence: Address: Rua Dr. Ovídio Pires de Campos, 785 São Paulo, SP - Brazil Postal code: 01060-970 fonoffet@usp.br

\section{SUMMARY}

Introduction: Low back pain is one of the painful disorders of higher prevalence. It has several etiologies and surgery may be indicated in the presence of neurological deficits or compression syndromes. However, in up to $40 \%$ of cases, patients develop worsening of pain and failed back surgery syndrome (FBSS), which is an important cause of chronic pain with high morbidity and disability. In the last two decades, ozone has been shown to be a new therapeutic option for FBSS due to its analgesic and anti-inflammatory properties.

Objective: To evaluate the effect of ozone therapy on pain and disability in patients with failed back surgery syndrome.

Method: We selected 19 patients undergoing epiduroscopy and injection of ozone. Patients were evaluated preoperatively and 21 days after the procedure, using the following instruments: Visual Analogue Scale (VAS), Brief Pain Inventory, Roland-Morris Questionnaire Disability, Oswestry Disability Index (ODI), Neuropathic Pain Symptom Inventory and Douleur Neuropathique 4.

Results: The patients showed significant pain relief, but no improvement was observed in the functional scales.

Conclusion: Our results suggest that epidural ozone therapy can be a treatment option in FBSS to reduce the intensity of the pain.

Keywords: low back pain, chronic pain, failed back surgery syndrome, ozone, epiduroscopy, Visual Analogue Scale.

\section{INTRODUCTION}

Low back pain (LBP) is one of the most prevalent pain disorders, ${ }^{1}$ and a frequent cause of morbidity and disability. It is estimated that about two-thirds of the population experience LBP at some point in their life, which is an important cause of sick leave in working-age adults. ${ }^{1,2}$ In the US, the prevalence of chronic LBP can reach $30 \%$, costing the country approximately US\$ 90 billion. In Brazil, there are no national statistics. A cross-sectional study conducted in Rio Grande do Sul found a prevalence of $4.2 \%$ for chronic LBP. ${ }^{3}$

LBP may be primary or secondary, and either present or not neurological impairment. The origin of the pain can be mechanical-degenerative, traumatic, congenital, neoplastic, inflammatory, infectious or metabolic, ${ }^{1,4,5}$ the first being more frequent. Many patients with LBP have musculoskeletal or degenerative changes that do not need specific treatment and are usually self-limiting. In more than $85 \%$ of LBP cases, there is no specific cause. ${ }^{6}$ Most cases of LBP are acute (also known as lumbago), have a good prognosis and usually resolve within four weeks. Some patients may have persistent symptoms and the improvement period may extend up to 12 weeks (subacute LBP). ${ }^{1,7}$ However, a minority of patients develop persistent pain for more than 12 weeks (chronic LBP), and pain and disability may persist relatively constantly. ${ }^{1,8}$

Several factors may contribute to the aggravation and chronification of LBP syndromes, such as smoking, obesity, chronic diseases, educational level, posture habits and other conditions that compromise quality of life. ${ }^{4,9}$ Imaging studies of the spine may reveal abnormalities such as disc degeneration, vertebral disc herniation and 
joint facet arthropathy, which may not correlate with clinical findings, particularly in the elderly. ${ }^{4,10}$

As an initial therapeutic measure for LBP, rest is indicated in all cases. ${ }^{11}$ Symptomatic treatment can be performed with analgesics, non-hormonal anti-inflammatory drugs, corticosteroids, muscle relaxants, benzodiazepines or tricyclic antidepressants, according to the underlying disease, as well as physiotherapy and weight control. ${ }^{1,4,5}$ In cases where conservative treatment was not satisfactory, when there are neurological deficits and/ or compressive syndromes, surgery should be considered. ${ }^{12,13}$ Of the surgical indications associated with LBP, disc herniation is one of the most frequent. Surgery may be performed through an open approach (hemilaminectomy plus flavectomy at the level of the involved spinal root, as well as hernia repair) $)^{2}$ or using a minimally invasive procedure. ${ }^{12}$ According to Martin et al. ${ }^{14}$ the failure rates of surgery for degenerative diseases of the lumbar spine may exceed $40 \%$ in the first year. Therefore, there may be poorly indicated surgeries, which contributes to the worsening of pain and favors a progression to failed back surgery syndrome (FBSS). ${ }^{2}$

FBSS is defined as "spinal lower back pain of unknown origin that persists at the same site of the original pain despite surgical interventions, or appears after the procedure."' Despite the term "unknown origin," it is believed that the causes of FBSS include disc infection, ${ }^{15}$ epidural fibrosis and local arachnoiditis, ${ }^{16}$ and even joint facet instability due to reduced intervertebral space and consequently altered vertebral angle. FBSS is more frequent as myofascial pain syndrome (MPS), being diagnosed in $85.7 \%$ of these patients. ${ }^{2}$ MPS is a regional musculoskeletal pain derived from trigger points with motor dysfunction and autonomic phenomena, which usually affect one or more muscle groups. A neuropathic pattern, alone or associated with MPS, is less frequent. ${ }^{2}$

Among the treatment modalities for cases that progress to FBSS, conservative behaviors, such as medication and rehabilitation, often yield unsatisfactory results. ${ }^{17}$ Retrospective studies suggest that surgical revisions tend to have lower rates of improvement than the initial procedure. ${ }^{18-20}$ Some authors mention that lysis of epidural adhesions may be a therapeutic option, ${ }^{2,21}$ but there is no consensus. ${ }^{22}$ Treatment with spinal cord stimulation $^{23,24}$ and intrathecal drug delivery ${ }^{25,26}$ produce good results, but these are procedures that involve high cost and limited availability. Nevertheless, compared with the costs related to hospital stay and reoperation, these procedures may actually cost less and provide better long-term results. ${ }^{27}$
In the last two decades, the application of ozone has emerged as a potential therapeutic option for patients with FBSS. It is suggested that ozone is useful for treating LBP due to its analgesic and anti-inflammatory properties. ${ }^{28,29}$ Although ozone therapy is not validated to treat FBSS, its cost is low and it is a minimally invasive procedure, which opens a new therapeutic horizon for the treatment of FBSS, a condition known to be debilitating and whose treatment is often frustrating for both physicians and patients.

\section{Method}

A retrospective analysis was carried out including 19 patients treated with epiduroscopy for adhesiolysis ${ }^{30}$ and $20 \mathrm{~mL}$ of a ozone-oxygen mixture at the concentration of $30 \mathrm{ug} / \mathrm{mL}$ from January 2013 to June 2014, following the protocol published by Magalhães. ${ }^{28}$ The patients came from the Pain Center of the Department of Neurology of the Faculty of Medicine of the University of São Paulo and were selected according to the following criteria:

- Inclusion criteria: Age between 18 and 70 years including both sexes; being able to inform the requested data, either in the presence of chronic radiating LBP or not, resulting from herniated disc for more than one year; having undergone surgery and progressed without improvement, presenting symptoms and diagnosis of FBSS.

- Exclusion criteria: Diagnosis of blood dyscrasia, hemophilia, hemolytic anemia, oncological diseases, acute or chronic infections, pregnancy, psychiatric conditions, diabetic neuropathy; diagnosis of favism and hyperthyroidism, which are contraindications to ozone therapy; presence of lumbosacral abnormality that could make the procedure unfeasible; other abnormalities in the spine such as segmental instability, canal stenosis, spondylolisthesis or scoliosis $>20^{\circ}$.

Pain and disability assessments were performed based on specific scales and validated in Portuguese. Visual Analogue Scale (VAS) and Neuropathic Pain Symptom Inventory (NPSI) were used to assess pain. The Oswestry Disability Index (ODI) and the Roland Morris Disability Questionnaire were used for disability. The Brief Pain Inventory (BPI) assesses both pain intensity and disability caused by it, and therefore was also included. The Neuropathic Pain Diagnostic Questionnaire (Douleur Neuropathique 4 - DN4) was used to diagnose neuropathic pain. The selected patients were interviewed and examined until a week before and 21 days after epiduroscopy with ozone therapy, and the scales were applied on both occasions. 


\section{RESULTS}

The patients' ages ranged from 24 to 66 years (mean 46.1), $63.16 \%$ were male and $36.84 \%$ were female. Just under a third had attended higher education. Half of the patients were on leave from work because of pain, unemployment or retirement. Smoking was reported by $21.1 \%$ and alcohol abuse by $10.5 \%$ of the patients. Associated diseases included type 2 diabetes mellitus, dyslipidemia, fibromyalgia and bipolar disorder. Other diseases such as tuberculosis, Hansen's disease, Chagas disease and neoplasms were not observed in the sample. The main diagnoses associated with pain were radiculopathy $(57.89 \%)$, followed by low back and leg pain (36.84) and low back pain (5.26\%). In only three cases the pain was related to a history of trauma to the lumbar spine. The mean time to onset of pain was 12.5 years. More than one surgery was indicated for the treatment of pain in $57.9 \%$, and in $63.16 \%$ of the cases lumbar spine arthrodesis was performed, without significant pain improvement (Table 1).

\section{TABLE 1 Clinical characteristics of patients.}

\begin{tabular}{|c|c|c|}
\hline Characteristic & & n (\%) \\
\hline Mean age $(S D)^{*}$ & $46.1 \pm 10.7$ & \\
\hline Sex & Male & $12(63.16)$ \\
\hline & Female & $7(36.84)$ \\
\hline Education & Primary and middle school & $10(52.63)$ \\
\hline & High school & $4(21.05)$ \\
\hline & Higher studies & $5(26.32)$ \\
\hline Occupation & Homemaker & $1(5.26)$ \\
\hline & Active & $5(26.32)$ \\
\hline & On sick leave $e^{* *}$ & $5(26.32)$ \\
\hline & Retired & $3(15.79)$ \\
\hline & Unemployed & $5(26.32)$ \\
\hline Comorbidities & Diabetes & $3(15.79)$ \\
\hline & Dyslipidemia & $1(5.26)$ \\
\hline & Fibromyalgia & $2(10.53)$ \\
\hline & Bipolar affective disorder & $1(5.26)$ \\
\hline Habits & Alcohol abuse & $2(10.53)$ \\
\hline & Smoking & $4(21.05)$ \\
\hline Trauma-related pain & Yes & $2(10.53)$ \\
\hline & No & $16(84.21)$ \\
\hline Site of pain & L5 & $14(73.68)$ \\
\hline & $\mathrm{L} 5+\mathrm{S} 1$ & $4(21.05)$ \\
\hline & S1 & $1(5.26)$ \\
\hline Duration of pain & $12.5 \pm 6.5$ & \\
\hline Number of surgeries & 1 & $8(42.11)$ \\
\hline & 2 & $6(31.58)$ \\
\hline & $\geq 3$ & $5(26.32)$ \\
\hline
\end{tabular}

TABLE 1 (Cont.) Clinical characteristics of patients.

\begin{tabular}{lll} 
Characteristic & & $\mathbf{n}(\%)$ \\
\hline Arthrodesis & Yes & $12(63.16)$ \\
\cline { 2 - 3 } & No & $7(36.84)$ \\
\hline Additional treatments & Physiotherapy & $19(100)$ \\
\cline { 2 - 3 } & Acupuncture & $17(89.47)$ \\
\cline { 2 - 3 } & Trigger point deactivation & $1(5.26)$ \\
\cline { 2 - 3 } & Psychotherapy & $8(42.11)$ \\
\cline { 2 - 3 } & Previous epiduroscopy & $4(21.05)$ \\
\hline
\end{tabular}

* Mean age plus standard deviation (SD); ** Patient on sick leave through the social security system

Of the 19 patients, 18 scored higher than or equal to 4 on the DN4 questionnaire, being diagnosed with neuropathic pain. However, during clinical evaluation, we observed that 17 patients had a mixed pain pattern, 12 with predominantly neuropathic pain (PNP) and seven with predominantly non-neuropathic pain (PNNP).

There was a mean reduction in the VAS scale from 8.47 to 7.05 , which was statistically significant (Figure 1A). There was a significant reduction in NPSI from 62.74 to 54.21 points $(\mathrm{p}=0.034)$. In the ODI assessment, no significant improvement in disability was observed after the procedure $(\mathrm{p}=0.217)$. A similar result was observed with the Roland-Morris questionnaire, which obtained a mean decrease from 14.47 to 13.84 , although not statistically significant $(\mathrm{p}=0.438)$. Functional impairment was also evident in the BPI of the patients, since in the field that assessed interference in daily activities there was a nonsignificant reduction from 7.63 to 6.71 . However, similarly to VAS and NPSI, BPI showed a statistically significant reduction in pain intensity from 7.68 to 6.58 (Table 2).

Comparing the results obtained in the PNP and PNNP groups, no significant difference ( $p>0.05$ ) was observed in the postoperative reevaluation scores, both for VAS (Figure 1B) and for the other scales.

\section{Discussion}

The first records of the use of ozone for medicinal purposes date back to the early twentieth century during the First World War. Its germicidal and analgesic effect was observed in the treatment of post-traumatic gas gangrene in German soldiers. ${ }^{31}$

Currently, ozone used for therapeutic purposes is a mixture of oxygen and ozone at $5 \%$. The gas has a cell oxidation and diffusion capacity ten times higher than that of oxygen. These characteristics suggest that, when ozone comes into contact with biologically active tissue, it reacts with numerous organic molecules forming sev- 


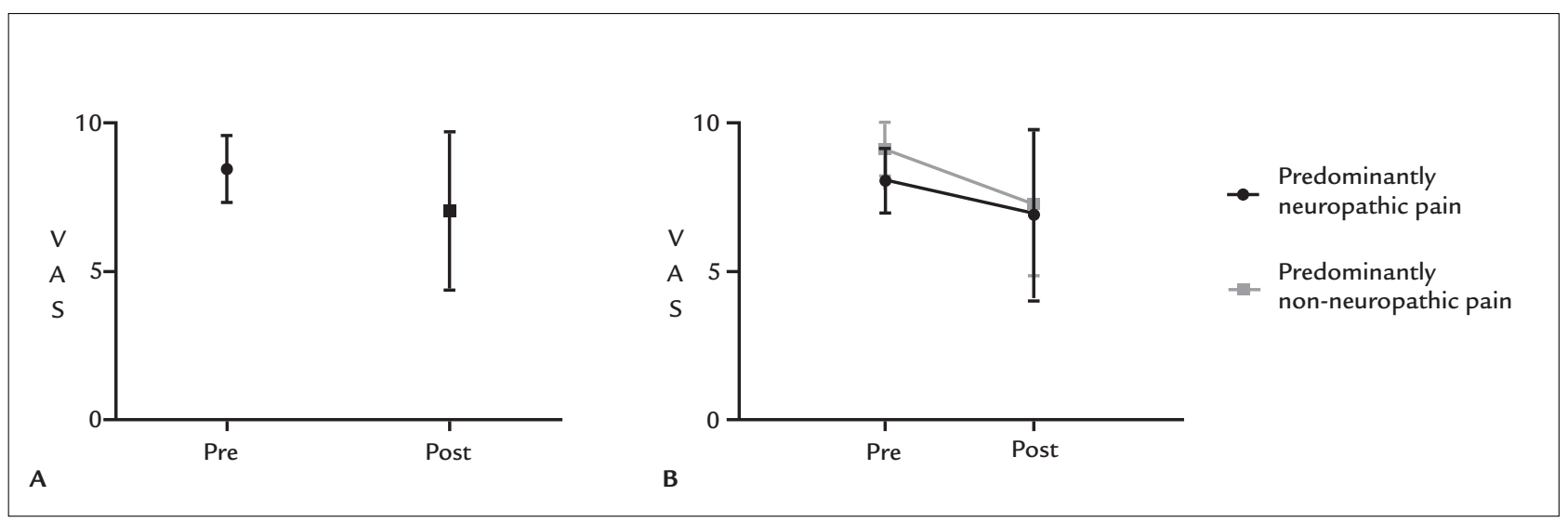

FIGURE 1 A. Statistical analysis of VAS after epiduroscopy with ozone injection, evidencing a significant reduction in scores (Student's paired t-test with $p<0.05$ ). B. Comparison of VAS in patients with PNP and PNNP pain (Repeated Measures ANOVA with $p>0.05$ ).

TABLE 2 Mean of results obtained from the scales applied before and 21 days after the procedure $(n=19)$.

\begin{tabular}{|c|c|c|c|c|}
\hline Scales & & Pre-surgery* & 21 days* & $\mathbf{p}^{* *}$ \\
\hline Visual Analogue Scale (VAS) & & $8.47( \pm 1.12)$ & $7.05( \pm 2.68)$ & 0.029 \\
\hline Neuropathic Pain Symptom Inventory (NPSI) & & $62.74( \pm 20.99)$ & $54.21( \pm 28.50)$ & 0.034 \\
\hline Oswestry Disability Index (ODI) & & $37.58( \pm 5.58)$ & $35.84( \pm 7.62)$ & 0.217 \\
\hline Roland-Morris Disability Questionnaire & & $14.47( \pm 5.08)$ & $13.84( \pm 6.32)$ & 0.438 \\
\hline \multirow[t]{2}{*}{ Brief Pain Inventory (BPI) } & Intensity & $7.86( \pm 1.11)$ & $6.58( \pm 2.15)$ & 0.005 \\
\hline & Interference & $7.63( \pm 1.54)$ & $6.71( \pm 2.45)$ & 0.054 \\
\hline
\end{tabular}

*Scale values expressed as mean and standard deviation; **Student's paired t-test.

eral enzymatic and non-enzymatic buffering systems, with anti-inflammatory and analgesic action. ${ }^{31-33}$

Ozone's mechanism of action in the treatment of FBSS is little known. Current hypotheses suggest that its effect could occur through chemical adhesiolysis of scar fibrosis associated with pain and dehydration of the herniated disc contents, ${ }^{31}$ as well as the activation of cytokines that would inhibit proinflammatory factors associated with chronic pain. ${ }^{32}$ It is believed that ozone may cause local vasodilation, favoring the neutralization of acidosis and the induction of antioxidant enzymes associated with analgesia, as well as stimulating the activation of the descending antinociceptive system, blocking the transmission of pain to the thalamus and cortex. ${ }^{33}$

Interest in the effects of ozone therapy to treat FBSS has been growing in the last two decades. Intradiscal and paravertebral ozone injection associated with a steroid and local anesthetics have presented significant results. Gallucci et al. ${ }^{34}$ compared the effect of adding ozone to a mixture of steroid and anesthetic in 159 patients. They reported that the ozone-treated group showed more improvement than the patients who did not receive it within six months of follow-up. In addition to the role of ozone in FBSS, Bonetti et al..$^{35}$ suggest that its analgesic action is also reproducible in chronic LBP and lumbago with sciatica.

When evaluating the intraforaminal effect of ozone versus steroidal infiltration in 306 patients, the authors observed that those treated with the oxygen-ozone mixture showed more improvement than the group treated with corticosteroids alone. In a meta-analysis by Magalhães et al. ${ }^{29}$ the level of evidence attributed to long-term pain relief was II- 3 in the case of intradiscal ozone and II- 1 for paravertebral ozone. Although the evidence corroborates the efficacy of intradiscal and paravertebral ozone injection, there is still little data on epiduroscopy-assisted use. In a pilot study with 13 patients published by Magalhães et al., ${ }^{28}$ the effect of the ozone-oxygen mixture versus oxygen in the epidural space was compared after adhesiolysis. Patients with PNNP presented a significant reduction in pain and disability according to ODI, whereas in the PNP group this reduction was not significant, which 
shows that ozone therapy may present better results to decrease pain and disability in patients with PNNP.

In addition to pain, FBSS causes great incapacity, insecurity and feelings of disability, conditions that can compromise the professional and family life of patients, causing great damage to their overall function and quality of life. In a cross-sectional study with 177 patients with chronic LBP, Salvetti et al. ${ }^{36}$ found the prevalence of disability at $68 \%$.

All patients evaluated in our study had a high degree of disability due to FBSS. During the evaluation 21 days after epiduroscopy, a significant decrease in pain intensity on the VAS and BPI scales (intensity field) was observed in $19.34 \%$ and $16.28 \%$ of patients, respectively. The reduction in intensity was consistent with the reduction in paroxysm and duration of pain found on the NPSI scale. However, this result was not seen in the functional evaluation using the ODI and Roland-Morris scales, which presented a non-significant decrease in the scores (Table 2) that evaluated daily activities such as personal care, sleep, social and sexual function, and mobility. This result may be related to the homogeneity of the sample, which includes only patients diagnosed with FBSS who presented moderate to high degree of disability, while other studies evaluated mixed populations, with other causes of chronic LBP. As the occurrence of litigation was not investigated in these patients, it is not possible to ascertain the effect of such variable in this population. Epiduroscopy-assisted ozone therapy is considered a low risk procedure with few complications, including accidental dural injury and epidural bleeding. Doses of ozone above the therapeutic range of 10 to $40 \mathrm{ug} / \mathrm{mL}$ may cause vagal vessel reflex, syncope and gas embolism. ${ }^{28}$ No complications were reported in this series.

\section{Conclusion}

FBSS-related pain is a debilitating condition that is difficult to treat. Ozone therapy has emerged with a therapeutic option in the management of pain and disability in these patients. The results of our study confirm its usefulness and show a decrease in pain intensity in patients with both PNP and PNNP. However, double-blind and controlled studies are needed to understand the long-term effects of ozone and to determine the effectiveness of the procedure.

\section{Resumo}

Efeitos do ozônio na dor e na incapacidade em pacientes com síndrome dolorosa pós-laminectomia
Introdução: A dor lombar é um dos distúrbios dolorosos de maior prevalência. Tem diversas etiologias e, na presença de déficits neurológicos ou síndromes compressivas, pode ser indicada cirurgia. Entretanto, em até $40 \%$ dos casos os pacientes podem evoluir com piora da dor $\mathrm{e}$ síndrome dolorosa pós-laminectomia (SDPL), que se constitui em uma importante causa de dor crônica com grande morbidade e incapacidade. Nas últimas duas décadas, o ozônio tem se mostrado uma nova opção terapêutica para a SDPL em virtude das suas propriedades analgésicas e anti-inflamatórias.

Objetivo: Avaliar o efeito da ozonioterapia na dor e na incapacidade de pacientes com SDPL.

Método: Foram selecionados 19 pacientes, submetidos a epiduroscopia e aplicação de ozônio. Os pacientes foram avaliados no pré-operatório e 21 dias após o procedimento, por meio de Escala Visual Analógica, Inventário Breve de Dor, Questionário Roland-Morris de Incapacidade, Oswestry Disability Scale, Inventário de Sintomas de Dor Neuropática e Questionário de Dor Neuropática.

Resultados: Os pacientes apresentaram redução significante nos escores das escalas de avaliação de dor; porém, essa redução não foi observada na avaliação da incapacidade funcional.

Conclusão: Os dados obtidos sugerem que a ozonioterapia epidural pode ser uma opção de manejo da SDPL na diminuição da intensidade da dor.

Palavras-chave: lombalgia, dor crônica, síndrome pós-laminectomia, ozônio, epiduroscopia, Escala Visual Analógica.

\section{References}

1. Chou R, Hashimoto R, Friedly J, Fu R, Dana T, Sullivan S, et al. Pain management injection therapies for low back pain [Internet]. Rockville (MD): Agency for Healthcare Research and Quality (US); 2015. AHRQ Technology Assessments [cited 2015 May]. Available from: http://www.ncbi. nlm.nih.gov/books/NBK285206/.

2. Teixeira MJ, Yeng LT, Garcia OG, Fonoff ET, Paiva WS, Araujo JO. Failed back surgery pain syndrome: therapeutic approach descriptive study in 56 patients. Rev Assoc Med Bras. 2011; 57(3):286-91.

3. da Silva MC, Fassa AG, Valle NCJ. [Chronic low back pain in a Southern Brazilian adult population: prevalence and associated factors]. Cad Saúde Pública. 2004; 20(2):377-85

4. Brazil AV, Ximenes AC, Radu AS, Fernades AR, Appel C, Maçaneiro CH, et al. Diagnóstico e tratamento das lombalgias e lombociatalgias. Rev Bras Reumatol. 2004; 44(6):419-25

5. Chou R, Qaseem A, Snow V, Casey D, Cross JT, Shekelle P, et al. Diagnosis and treatment of low back pain: a joint clinical practice guideline from the American College of Physicians and the American Pain Society. Ann Intern Med. 2007; 147(7):478-91.

6. Deyo RA, Phillips WR. Low back pain. A primary care challenge. Spine. 1996; 21(24):2826-32.

7. Pengel LHM, Herbert RD, Maher CG, Refshauge KM. Acute low back pain: systematic review of its prognosis. BMJ. 2003; 327(7410):323. 
8. Chou R, Shekelle P. Will this patient develop persistent disabling low back pain? JAMA. 2010; 303(13):1295-302.

9. Kummel BM. Nonorganic signs of significance in low back pain. Spine. 1996; 21(9):1077-81.

10. van Tulder MW, Assendelft WJ, Koes BW, Bouter LM. Spinal radiographic findings and nonspecific low back pain. A systematic review of observational studies. Spine. 1997; 22(4):427-34.

11. Waddell G, Feder G, Lewis M. Systematic reviews of bed rest and advice to stay active for acute low back pain. Br J Gen Pract. 1997; 47(423):647-52.

12. Skovrlj B, Gilligan J, Cutler HS, Qureshi SA. Minimally invasive procedures on the lumbar spine. World J Clin Cases. 2015; 3(1):1-9.

13. Watters WC 3rd, Resnick DK, Eck JC, Ghogawala Z, Mummaneni PV, Dailey AT, et al. Guideline update for the performance of fusion procedures for degenerative disease of the lumbar spine. Part 13: injection therapies, low-back pain, and lumbar fusion. J Neurosurg Spine. 2014; 21(1):79-90.

14. Martin BI, Mirza SK, Comstock BA, Gray DT, Kreuter W, Deyo RA. Are lumbar spine reoperation rates falling with greater use of fusion surgery and new surgical technology? Spine. 2007; 32(19):2119-26.

15. Goupille P. Causes des échecs de la chirurgie discale. Rev Rhum. 1996; 63:255-60.

16. Willburger RE, Wittenberg RH. Prostaglandin release from lumbar disc and facet joint tissue. Spine. 1994; 19(18):2068-70.

17. Hussain A, Erdek M. Interventional pain management for failed back surgery syndrome. Pain Pract. 2014; 14(1):64-78.

18. Waddell G, Kummel EG, Lotto WN, Graham JD, Hall H, McCulloch JA Failed lumbar disc surgery and repeat surgery following industrial injuries. J Bone Joint Surg Am. 1979; 61(2):201-7.

19. North RB, Campbell JN, James CS, Conover-Walker MK, Wang H, Piantadosi $\mathrm{S}$, et al. Failed back surgery syndrome: 5-year follow-up in 102 patients undergoing repeated operation. Neurosurgery. 1991; 28(5):685-90; discussion 690-1.

20. Ragab A, Deshazo RD. Management of back pain in patients with previous back surgery. Am J Med. 2008; 121(4):272-8.

21. Slipman CW, Shin CH, Patel RK, Isaac Z, Huston CW, Lipetz JS, et al. Etiologies of failed back surgery syndrome. Pain Med. 2002; 3(3):200-14; discussion 214-7.

22. Trescot AM, Chopra P, Abdi S, Datta S, Schultz DM. Systematic review of effectiveness and complications of adhesiolysis in the management of chronic spinal pain: an update. Pain Physician. 2007; 10(1):129-46

23. Patel VB, Wasserman R, Imani F. Interventional therapies for chronic low back pain: a focused (efficacy and outcomes). Anesthesiol Pain Med. 2015; 5(4):e29716.
24. Gopal H, Fitzgerald J, McCrory C. Spinal cord stimulation for FBSS and CRPS: a review of 80 cases with on-table trial of stimulation. J Back Musculoskelet Rehabil. 2016; 29(1):7-13.

25. Lara NA Jr, Teixeira MJ, Fonoff ET. Long term intrathecal infusion of opiates for treatment of failed back surgery syndrome. Acta Neurochir Suppl. 2011; 108:41-7.

26. Valverde-Filho J, da Cunha Neto MBC, Fonoff ET, Meirelles ES, Teixeira MJ Chronic spinal and oral morphine-induced neuroendocrine and metabolic changes in noncancer pain patients. Pain Med. 2015; 16(4):715-25.

27. North RB, Kidd D, Shipley J, Taylor RS. Spinal cord stimulation versus reoperation for failed back surgery syndrome: a cost effectiveness and cost utility analysis based on a randomized, controlled trial. Neurosurgery. 2007; 61(2):361-8; discussion 368-9.

28. Magalhães O, Soares SC, Torres JM, Ungaretti A, Cacciacarro MF, Teixeira MJ, et al. Effects of ozone applied by spinal endoscopy in patients with chronic pain related to failed back surgery syndrome: a pilot study. Neuropsychiatr Dis Treat. 2013; 9:1759-66.

29. Magalhaes FN, Dotta L, Sasse A, Teixera MJ, Fonoff ET. Ozone therapy as a treatment for low back pain secondary to herniated disc: a systematic review and meta-analysis of randomized controlled trials. Pain Physician. 2012; 15(2):E115-29.

30. Fonoff ET, Lopez WOC, de Oliveira YSA, Lara NA, Teixeira MJ. Endoscopic approaches to the spinal cord. Acta Neurochir Suppl. 2011; 108:75-84.

31. Bocci VA. Scientific and medical aspects of ozone therapy. State of the art. Arch Med Res. 2006; 37(4):425-35.

32. Cappello C, Saugel B, Huth KC, Zwergal A, Krautkrämer M, Furman C, et al Ozonized low density lipoprotein (ozLDL) inhibits NF-kappaB and IRAK-1-associated signaling. Arterioscler Thromb Vasc Biol. 2007; 27(1):226-32.

33. Bocci V, Borrelli E, Zanardi I, Travagli V. The usefulness of ozone treatment in spinal pain. Drug Des Devel Ther. 2015; 9:2677-85

34. Gallucci M, Limbucci N, Zugaro L, Barile A, Stavroulis E, Ricci A, et al Sciatica: treatment with intradiscal and intraforaminal injections of steroid and oxygen-ozone versus steroid only. Radiology. 2007; 242(3):907-13

35. Bonetti M, Fontana A, Cotticelli B, Volta GD, Guindani M, Leonardi M. Intraforaminal $\mathrm{O}(2)-\mathrm{O}(3)$ versus periradicular steroidal infiltrations in lowe back pain: randomized controlled study. AJNR Am J Neuroradiol. 2005; 26(5):996-1000.

36. Salvetti MG, Pimenta CA, Braga PE, Corrêa CF. [Disability related to chronic low back pain: prevalence and associated factors]. Rev Esc Enferm USP. 2012; 46 Spec No:16-23. 